\title{
Effects of Indocyanine green on cultured retinal ganglion cells in-vitro
}

\author{
S Balaiya, Vikram S Brar, Ravi K Murthy and KV Chalam*
}

Address: University of Florida College of Medicine, Department of Ophthalmology Jacksonville, FL, USA

Email: S Balaiya - sbalaiya@jax.ufl.edu; Vikram S Brar - vikram.brar@jax.ufl.edu; Ravi K Murthy - ravi.keshavamurthy@jax.ufl.edu; KV Chalam* - kvchalam@aol.com

* Corresponding author

Published: 25 November 2009

BMC Research Notes 2009, 2:236 doi:10.1/86/1756-0500-2-236
Received: 7 April 2009

Accepted: 25 November 2009

This article is available from: http://www.biomedcentral.com/1756-0500/2/236

(c) 2009 Chalam et al; licensee BioMed Central Ltd.

This is an Open Access article distributed under the terms of the Creative Commons Attribution License (http://creativecommons.org/licenses/by/2.0), which permits unrestricted use, distribution, and reproduction in any medium, provided the original work is properly cited.

\begin{abstract}
Background: Indocyanine green (ICG) dye is commonly used to stain the inner limiting membrane during macular surgery. There are reports documenting the toxicity of ICG on retinal pigment epithelial cells, with conflicting results in retinal ganglion cells. In the present study, we evaluated the effect of ICG on retinal ganglion cells in vitro.

Cultured rat retinal ganglion cells (RGC-5) were exposed to different concentrations of ICG $(0.25$, $0.5,1.0,1.25, \& 5 \mathrm{mg} / \mathrm{ml})$ and at various time intervals $(1,5,15,30, \& 60$ minutes). Changes in structural morphology were identified using phase contrast bright field microscopy. Cell viability was quantified using the neutral red assay and cell death was characterized using Annexin-V staining.

Findings: Significant morphologic changes were observed at the 15 and 60 min intervals for all concentrations, where a reduction in cell size and loss of normal spindle shape was noted. A dose dependent decrease in cell viability was observed with increasing concentration of ICG as well as increasing exposure intervals. Compared to control, $48-74 \%$ reduction in neutral red uptake at all concentrations for exposures $5 \mathrm{~min}$ or greater $(p<0.00 \mathrm{I})$. Even at I min exposure, a dose dependent decline was observed in cell viability, with a $28-48 \%$ decline for doses above $1.25 \mathrm{mg} / \mathrm{ml}$ $(p=0.007)$. Staining with Annexin- $V$, demonstrated a similar dose and time dependent increase in number of cells exhibiting early apoptosis. A greater than two-fold increase in Annexin-V expression for all doses at exposures greater than I min was noted.
\end{abstract}

Conclusion: ICG dye exhibits toxicity to retinal ganglion cells at clinically relevant doses following I min exposure.

\section{Background}

Indocyanine green (ICG) is commonly used to stain the internal limiting membrane (ILM) $[1,2]$ during macular surgery for the treatment of idiopathic macular holes [3$5]$ and diffuse diabetic macular edema [6]. However, the safety of intravitreal use of ICG is not well established.
Adverse effects such as visual field defects [7-9] and atrophy of the retinal ganglion cell layer [10] subsequent to ICG assisted membrane peeling have been reported. The underlying cause of ICG-related adverse effects has been proposed to be due to the osmolarity of the solution [11] or photochemical damage [12]. 
The retinal ganglion cell (RGC) layer is the first to come in contact with ICG dye used for staining in macular surgery and theoretically has the maximum exposure to the dye. A number of animal and in-vitro studies have evaluated the toxicity of ICG in cell culture models [13-18]. However, there is conflicting data with regards to presence of ICG mediated toxicity.

In this study, we investigated the effect of different ICG concentrations at specific time intervals on rat RGCs (RGC-5), in vitro, to establish a safe dose for use in-vivo. We specifically evaluated the effect of ICG on morphology, cell viability, and mechanism of cell death.

\section{Methods \\ Cell Culture}

Rat retinal ganglion cells (RGC-5) were graciously donated by Dr. Neeraj Agarwal, University of North Texas. RGC-5 cells were maintained in log-rhythmic growth and cultured in Dulbecco's modified Eagle's medium (DMEM: L-glutamine, $110 \mathrm{mg} / \mathrm{L}$ sodium bicarbonate and $1 \mathrm{~g} / \mathrm{L} \mathrm{D-}$ glucose) containing 10\% fetal bovine serum (JRH Biosciences, Lenexa, Ka) and $100 \mathrm{U} / \mathrm{ml}$ of penicillin and 100 $\mu \mathrm{g} / \mathrm{ml}$ of streptomycin. The cells were maintained in 75 $\mathrm{cm}^{2}$ filter-capped cell culture flasks and incubated with $5 \% \mathrm{CO}_{2}$ at $37^{\circ} \mathrm{C}$.

\section{ICG Preparation}

$25 \mathrm{mg}$ of ICG (Acorn, IL) was diluted in $5 \mathrm{ml}$ phosphatebuffered saline with albumin (PBSA) to obtain a $5 \mathrm{mg} / \mathrm{ml}$ mixture. The prepared solution was further diluted to obtain ICG concentrations of $0.25,0.5,1.0,1.25$, and 5 $\mathrm{mg} / \mathrm{ml}$. ICG solution was prepared fresh for each experiment. The osmolarity of the prepared ICG solutions ranged between 309 and 313 mosm/litre.

\section{ICG Staining}

The RGCs were grown in 24-well culture plates (Corning, Corning, NY) for 24 hours in conditioned cell culture media. The culture medium was aspirated from each of the 24-well culture plates and replaced with the various ICG concentrations. RGCs were exposed to the various concentrations of ICG $(0,0.25,0.5,1.0,1.25$ and $5 \mathrm{mg} /$ $\mathrm{ml}$ ) for 1, 5, 15, 30 and 60 minutes. Cultures containing PBSA alone served as control. Following exposure to ICG dye, cells were washed with PBS and were subsequently cultured for 2 hours in DMEM, at which point the experiments were concluded.

\section{Structural Morphology}

Glass cover slips with RGC cells exposed to different ICG concentrations $(0,0.25,0.5,1.0,1.25,5 \mathrm{mg} / \mathrm{ml})$ were washed twice with PBS and mounted on a slide using crystal mount solution. The slides were analyzed by bright field microscopy (Olympus U-RFL-T) to identify morphological changes.

\section{Cell viability by Neutral Red (NR) Uptake Assay}

The NR uptake assay was done as previously described [19]. Briefly, NR working solution $(0.033 \%)$ was freshly prepared for each experiment by diluting $1 \mathrm{ml}$ of NR stock solution (0.5\% (Sigma Aldrich, St. Louis, MO) in $14.5 \mathrm{ml}$ of DEPC (Sigma Aldrich, St. Louis, MO). After ICG exposure, an equal volume of fresh media supplemented the ICG solution containing $33 \mu \mathrm{l}$ of NR working solution. The cells were allowed to incubate at room temperature (RT) for $2 \mathrm{~h}$. After incubation, the NR solution was aspirated and the attached cells were washed twice with PBS, before allowing too air-dry at RT for 20 minutes. The cells were treated with ice-cold solubilization buffer ( $1 \%$ acetic acid/50\% ethanol; $300 \mu \mathrm{L}$ ) to release the remaining NR from the internal compartments of the cell for $30 \mathrm{~min}$ utes. The absorbance was measured at $490 \mathrm{~nm}$ using a Bio-Tek ELX 800 microplate reader.

\section{Evaluation of Apoptosis with Flow Cytometry}

$8 \times 10^{3}$ RGC-5 cells were isolated and centrifuged. Cells were then washed twice with PBS and resuspended in $1 \times$ binding buffer (10 mM HEPES/NaOH, $140 \mathrm{mM} \mathrm{NaCl}$, and $\left.2.5 \mathrm{mM} \mathrm{CaCl}_{2}, \mathrm{pH} 7.5\right) .500 \mu \mathrm{l}$ of each experimental cell suspension was added to different tubes and stained with $5 \mu$ l of Annexin V-FITC. After incubating the tubes at room temperature for 10 minutes, the fluorescence was analyzed by flow cytometry (Epics XL-MLC, Becton Dickinson, Mountain View, CA). The 0.25, 0.50, and $1.0 \mathrm{mg} /$ $\mathrm{ml}$ concentrations of ICG were evaluated.

\section{Statistical analysis}

Statistical analysis of the data was done using Student's $t$ test (Graphpad Prizm, Version3, CA, US). A p value of less than 0.05 was considered significant.

\section{Results}

\section{Cell Morphology}

After 1 and 5-minute incubation at all ICG concentrations, the cells continued to show similar structural features compared to controls. However, there was a significant morphological variation after 15 and 60minute incubation, at all concentrations. The cells assumed an oval shape and were reduced in size compared with longer spindle shaped control. (Figure 1)

\section{Cell Viability Assay (Neutral Red)}

RGC cells exposed to concentrations as low as $0.25 \& 0.5$ $\mathrm{mg} / \mathrm{ml}$ demonstrated reduced $\mathrm{NR}$ uptake as early as 1 min. A 12 and 14\% reduction in cell viability was noted respectively. At the same exposure time, the $1.0 \& 1.25$ $\mathrm{mg} / \mathrm{ml}$ doses, demonstrated a 21 and $28 \%$ reduction, with 

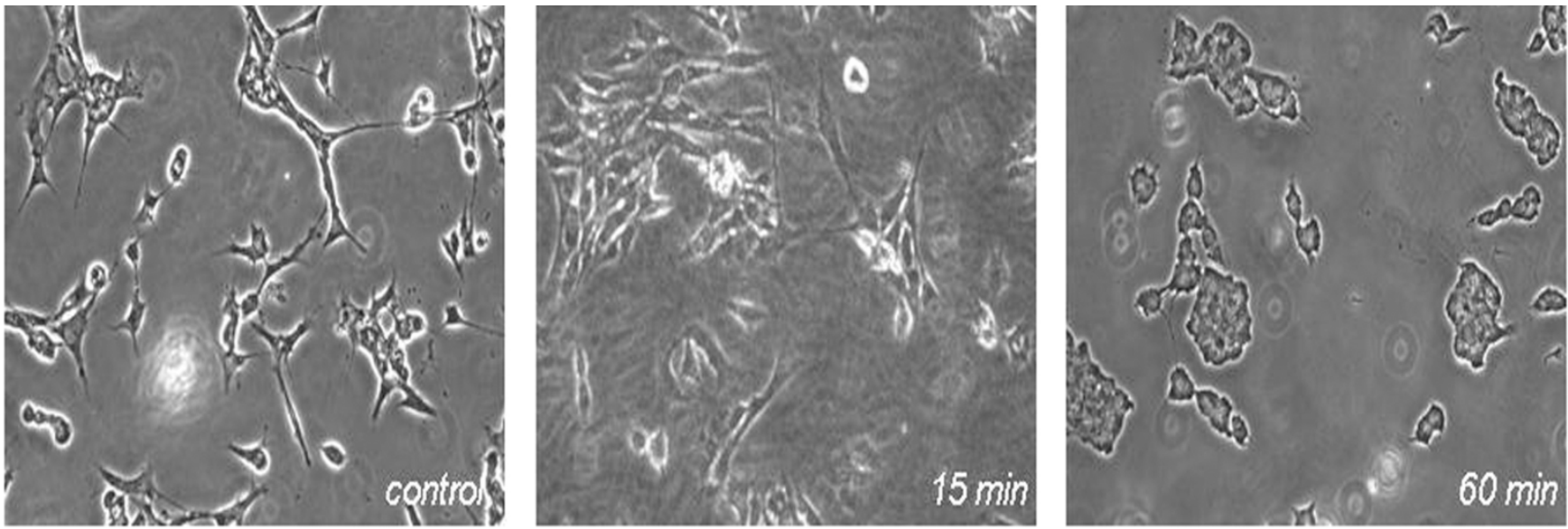

Figure I

Morphologic changes following exposure to ICG dye. Representative images at $0.5 \mathrm{mg} / \mathrm{ml}$ concentration were obtained with phase contrast microscopy. Cells became rounder and smaller with increasing duration of exposure.

a $43 \%$ reduction noted at the highest concentration $(\mathrm{p}=$ $0.007)$.

After 5 min exposure, the lowest concentration group, reduced cell viability by $48 \%$ compared with control. This trend continued with either an increase in dose or exposure time. The greatest reduction in cell viability was observed at the highest concentration at the longest exposure, where only $17.5 \%$ of the remaining cells were viable $(\mathrm{p}<0.001)$ (Figure 2).

\section{Flow Cytometry}

Flow cytometric analysis, revealed a parallel increase in Annexin- $V$ detection compared with the results of the neutral red assay. Following $1 \mathrm{~min}$ exposure, both 0.25 and $0.50 \mathrm{mg} / \mathrm{ml}$ concentrations, demonstrated a $45 \%$ increase in apoptotic cells compared with control. Similar to the results from the cell viability assay, increased duration at the lowest concentration, correlated with a 2.5 fold increase in percentage of apoptotic cells.

The greatest separation among the various doses was evident at $15 \mathrm{~min}$ exposure interval. The $0.25 \mathrm{mg} / \mathrm{ml}$ concentration maintained a 2.5 fold increase in apoptotic cells,

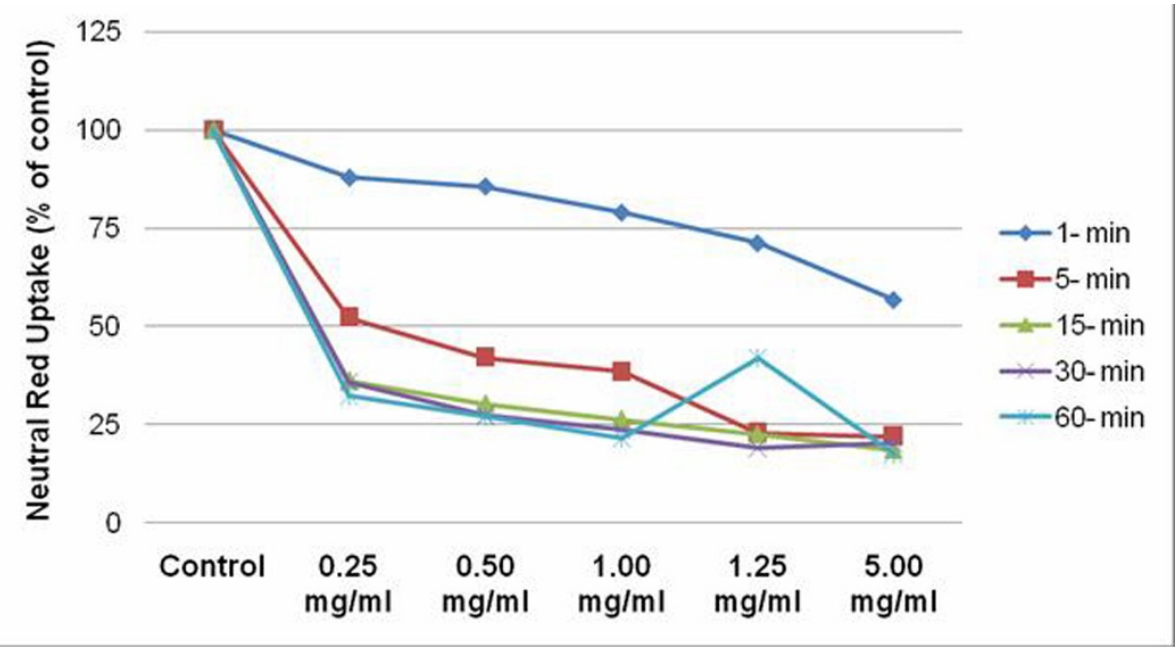

\section{Figure 2}

Cell viability evaluated by Neutral Red assay, demonstrates a dose and time dependent decrease in cell viability following ICG exposure. Data expressed as percent of control. 
where a 3 and 4 fold increase occurred for the 0.5 and 1.0 $\mathrm{mg} / \mathrm{ml}$ concentrations respectively. A similar relationship was maintained across the various doses for the remaining exposure times. (Figure 3)

\section{Discussion}

Indocyanine green (ICG) is an amphillic tricarbocyanine dye often used in macular surgery, where it stains the internal limiting membrane and facilitates its removal [16]. Both clinical [7-10] and experimental [11-17] reports have documented toxicity of ICG dye. However, there is a lack of standardization with regards to doses tested and exposure times evaluated. This study addresses this question by testing different concentrations (including the concentrations used in clinical setting: 0.25 and $0.5 \mathrm{mg} /$ $\mathrm{ml}$ ) at different exposure times, while adding to the body of literature relating to the mechanism of ICG mediated cell death.

Morphologic analysis demonstrated the toxic effects of ICG on retinal ganglion cells where evidence of toxicity was observed with increased exposure time. This becomes clinically relevant in cases of incomplete ICG removal or post surgical persistence of the dye [20]. These results were further supported by loss of cell viability in a dose and time dependent manner, where ICG toxicity was observed at the lowest concentration after $1 \mathrm{~min}$ exposure. It has been suggested that $1.25 \mathrm{mg} / \mathrm{ml}$, provides the optimal visibility of the ILM in clinical settings [21]. Our study demonstrated $29 \%$ reduction in cell viability at this concentration, following $1 \mathrm{~min}$ exposure. This is corrobo- rated by clinical studies which have reported visual filed defects after in-vivo use of $0.05 \%$ ICG for 1 minute during vitrectomy for macular hole surgery $[7,9]$.

Mechanistic studies have revealed that exposure to ICG results in apoptosis in the retinal cells [17]. In our study, we used Annexin- $\mathrm{V}$, a human anticoagulant that has strong attraction for phoshatidylserine residues, to detect apoptosis in the RGC cell line. Our results indicated as both time and concentration increased, the detection of Annexin-V increased. For doses $=0.50 \mathrm{mg} / \mathrm{ml}, 1$ minute exposure resulted in approximately $50 \%$ increase in apoptosis. However, at exposure time of 5 minutes, significant cell loss ( $>2$-fold) was observed irrespective of the concentration of the dye used. These results mirrored the loss in cell viability using the neutral red (NR) assay.

The limitation of the study is the use of an in-vitro model which does not factor the penetrability of ICG across the ILM.

\section{Conclusion}

Our work illustrates worsening cytotoxic effects of ICG to retinal ganglion cells in a dose and time-dependent manner. In addition, we have shown that cytotoxic effect occurs in the absence of any stimulating light. We suggest that the lower concentration and shorter staining time of ICG be used for staining ILM during vitrectomy. Complete and quick removal after injection over the macula is imperative to prevent detrimental changes to the retinal ganglion cells.

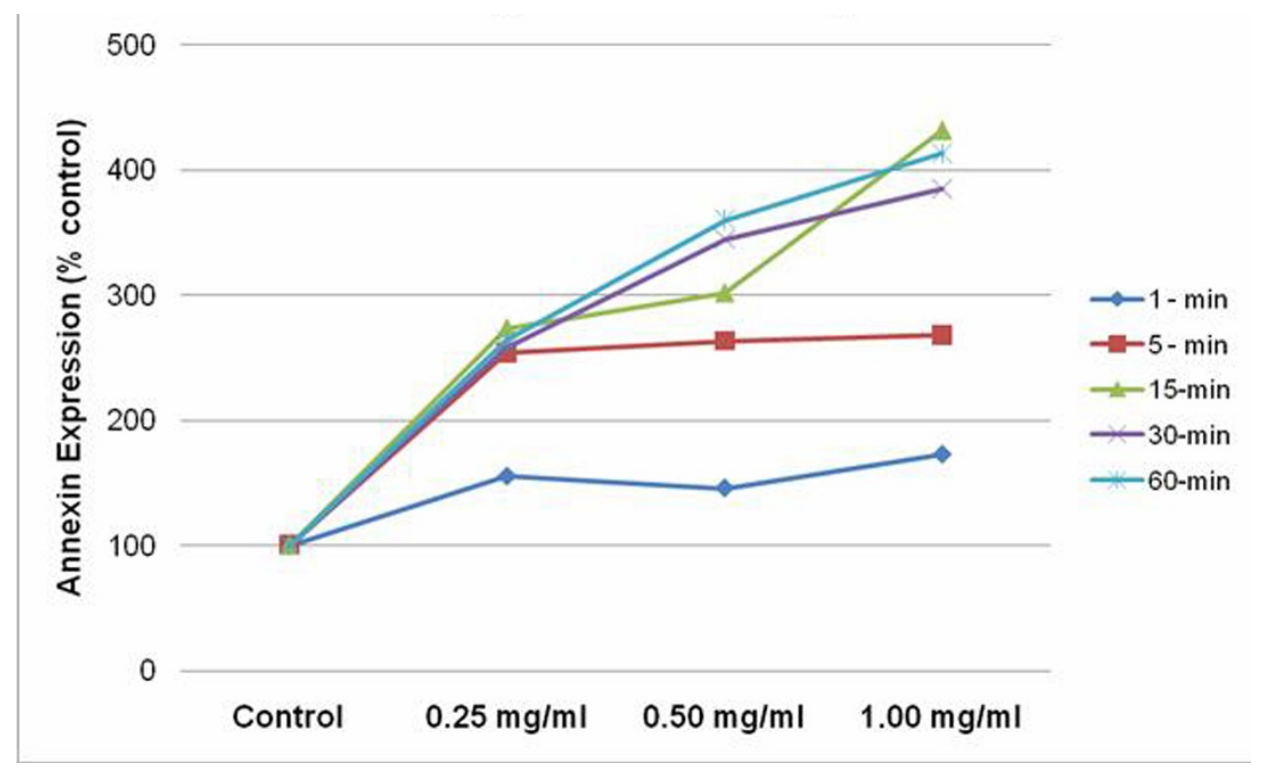

Figure 3

Annexin-V detection evaluated by flow cytometry, demonstrates a dose and time dependent increase in early apoptosis following ICG exposure. Data expressed as percent of control. 


\section{List of abbreviations}

ICG: Indocyanine green; RGC: Retinal ganglion cell; NR: Neutral red.

\section{Competing interests}

The authors declare that they have no competing interests.

\section{Authors' contributions}

KVC was involved in the conception and design of the study; SB was involved in the acquisition of data; VSB and RK were involved in the analysis of the data and preparation of the manuscript.

All authors have read and approved the final manuscript.

\section{References}

I. Burk SE, Da Mata AP, Snyder ME, Rosa RH Jr, Foster RE: Indocyanine green-assisted peeling of the retinal internal limiting membrane. Ophthalmology 2000, I07(I I):2010-4.

2. Gandorfer A, Messmer EM, Ulbig MW, Kampik A: Indocyanine green selectively stains the internal limiting membrane. Am J Ophthalmol 200I, I 3 I(3):387-8.

3. Kwok AK, Lai TY, Man-Chan W, Woo DC: Indocyanine green assisted retinal internal limiting membrane removal in stage 3 or 4 macular hole surgery. Br J Ophthalmol 2003, 87:7 I-74.

4. Ando F, Sasano K, Ohba N, Hirose H, Yasui O: Anatomic and visual outcomes after indocyanine green-assisted peeling of the retinal internal limiting membrane in idiopathic macular hole surgery. Am J Ophthalmol 2004, 137(4):609-14.

5. Da Mata AP, Burk SE, Foster RE, Riemann CD, Petersen MR, Nehemy $M B$, Augsburger JJ: Long-term follow-up of indocyanine greenassisted peeling of the retinal internal limiting membrane during vitrectomy surgery for idiopathic macular hole repair. Ophthalmology 2004, I I I ( I 2):2246-53.

6. Kamura $Y$, Sato $Y$, Isomae $T$, Shimada $H$ : Effects of internal limiting membrane peeling in vitrectomy on diabetic cystoid macular edema patients. Jpn J Ophthalmol 2005, 49(4):297-300.

7. Gass CA, Haritoglou C, Schaumberger M, Kampik A: Functional outcome of macular hole surgery with and without Indocyanine green-assisted peeling of the internal limiting membrane. Graefes Arch Clin Exp Ophthalmol 2003, 241:716-720.

8. Uemura A, Kanda S, Sakamoto Y, Kita H: Visual field defects after uneventful vitrectomy for epiretinal membrane with indocyanine green-assisted internal limiting membrane peeling. Am J Ophthalmol 2003, 136:252-257.

9. Hartoglou C, Gandorfer A, Gass CA, et al:: Indocyanine greenassisted peeling of the internal limiting membrane in macular hole surgery affects visual outcome: a clinicopathologic correlation. Am J Ophthalmol 2002, I34:836-84I.

10. Iriyama A, Yanagi Y, Uchida S, Tamaki Y, Aihara M, Obata R, Inoue Y: Retinal nerve fibre layer damage after indocyanine green assisted vitrectomy. Br J Ophthalmol 2004, 88:1606-7.

1I. Stalmans P, Van Aken EH, Veckeneer M, et al.: Toxic effects of indocyanine green on retinal pigment epithelium related to osmotic effects of the solvent. Am J Ophthalmol 2002, I34:282-285.

12. Sippy BD, Engelbrecht NE, Hubbard GB, et al.: Indocyanine green effect on cultured human retinal pigment epithelial cells: implications for macular hole surgery. Am J Ophthalmol 200I, 132:433-435.

13. Gandorfer A, Haritoglu C, Gandorfer A, Kampik A: Retinal damage from indocyanine green in experimental macular surgery. Invest Ophthalmol Vis Sci 2003, 44:316-323.

14. Gale JS, Proulx AA, Gonder JR, Mao AJ, Hutnik CM: Comparison of the in vitro toxicity of indocyanine green to that of trypan blue in human retinal pigment epithelium cell cultures. Am J Ophthalmol 2004, I 38(I):64-9.

15. Jackson TL, Hillenkamp J, Knight BC, Zhang J], Thomas D, Stanford $M R$, Marshall J: Safety testing of indocyanine green and trypan blue using retinal pigment epithelium and glial cell cultures. Invest Ophthalmol Vis Sci 2004, 45(8):2778-85.

16. Iriyama A, Uchida S, Yanagi $Y$, Tamaki Y, Inoue $Y$, Matsuura K, Kadonosono K, Araie M: Effects of Indocyanine Green on Retinal Ganglion Cells. Invest Ophthalmol Vis Sci 2004, 45(3):943-7.

17. Kawahara S, Hata Y, Miura M, Kita T, Sengoku A, Nakao S, Mochizuki $\mathrm{Y}$, Enaida H, Ueno A, Hafezi-Moghadam A, Ishibashi T: Intracellular events in retinal glial cells exposed to ICG and BBG. Invest Ophthalmol Vis Sci 2007, 48(10):4426-32.

18. Yuen D, Gonder J, Proulx A, Liu H, Hutnik C: Comparison of the in vitro safety of intraocular dyes using two retinal cell lines: a focus on brilliant blue $\mathbf{G}$ and indocyanine green. Am J Ophthalmol 2009, I47(2):25I-259.

19. Repetto G, del Peso A, Zurita JL: Neutral red uptake assay for the estimation of cell viability/cytotoxicity. Nat Protoc 2008, 3(7): || $25-3 \mid$

20. Weinberger AW, Kirchhof B, Mazinani BE, Schrage NF: Persistent indocyanine green (ICG) fluorescence 6 weeks after intraocular ICG administration for macular hole surgery. Graefes Arch Clin Exp Ophthalmol 200I, 239:388-390.

21. Kwok AK, Lai TY, Yew DT, Li WW: Internal limiting membrane staining with various concentrations of indocyanine green dye under air in macular surgeries. Am J Ophthalmol 2003, I36(2):223-30.
Publish with Bio Med Central and every scientist can read your work free of charge

"BioMed Central will be the most significant development for disseminating the results of biomedical research in our lifetime. "

Sir Paul Nurse, Cancer Research UK

Your research papers will be:

- available free of charge to the entire biomedical community

- peer reviewed and published immediately upon acceptance

- cited in PubMed and archived on PubMed Central

- yours - you keep the copyright 